\title{
Stock Market Integration and the Speed of Information Transmission
}

\author{
Alexandr Cerny
}
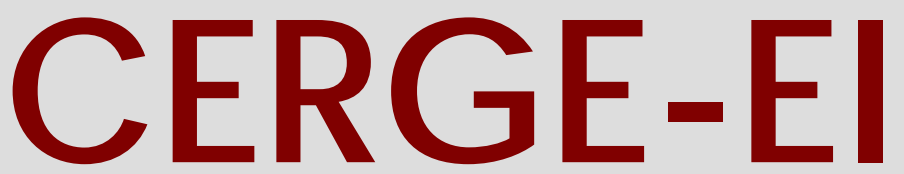

CharlesUniversity Centerfor Economic Research and Graduate Education Academy of Sciences of the Czech Republic

Ec onomic sInstitute 


\title{
Stock Market Integration and the Speed of Information Transmission
}

\author{
Alexandr Černý ${ }^{1}$ \\ August 2004
}

\begin{abstract}
:
Using a unique dataset covering 8 months of high frequency data on the indices from markets in the U.S., London, Frankfurt, Paris, Warsaw, and Prague, I investigate the issue of stock market integration from a novel perspective. Cointegration and Granger causality tests with data of different frequencies (from 5 minutes to 1 day) are performed. The aim is to describe the time structure in which markets react to the information revealed in prices on other markets. Particularly, I want to detect the speed of information transmission between the different markets. The results suggest that markets react very quickly to the information revealed in the prices on other markets. In all cases the reaction occurs as soon as within 1 hour. The U.S. markets seem to be an important source of information for the markets in London and Frankfurt, which react within 30 minutes, with the first reaction occurring already within 5 minutes. Information transmission between the market in London and any of the two continental markets in Paris or Frankfurt appears to be relatively unimportant compared to the information transmission between the two continental markets. The stock market in Paris seems to react to the information revealed at the stock market in Frankfurt with a delay of 40 minutes to 1 hour. Similarly, the two relatively small Eastern European markets in Warsaw and Prague are found to react to the information revealed in the stock market prices in Frankfurt. The reaction of the market in Prague seems to be faster, occurring within 30 minutes, while reaction speed of the market in Warsaw is around 1 hour.
\end{abstract}

\begin{abstract}
Abstrakt:
Tento článek používá nový prístup ke studiu integrace akciových trhů. Je testována kointegrace a Grangerova kauzalita mezi časovými řadami akciových indexů pro různé frekvence dat (od 5 minut do 1 dne). Testy jsou prováděny na jedinečné databázi pokrývající 8 měsícủ dat vysoké frekvence indexů akciových trhů v USA, Londýně, Frankfurtu, Paříži, Varšavě a Praze. Cílem tohoto článku je popsat časovou strukturu reakce jednotlivých trhů na informaci obsaženou $\checkmark$ cenách akcií na ostatních trzích, zejména pak detekovat rychlost přenosu informace mezi jednotlivými trhy. Výsledky provedených testů naznačuji že rychlost přenosu informace je velmi vysoká. Ve všech př́padech dochází k reakci do 1 hodiny. Trhy v USA se zdají být významným zdrojem informace pro trhy $v$ Londýně a Frankfurtu, které reagují na změny cen akcií $v$ New Yorku během 30 minut, prič̌emž k první reakci dochází již po 5 minutách. Přenos informace mezi trhem $v$ Londýně a kontinentálními trhy $v$ Pařiži a Frankfurtu se zdá být relativně nevýznamný ve srovnání $s$ přenosem informace mezi těmito dvěma kontinentálními trhy. Akciový trh $v$ Pařiži reaguje na informaci obsaženou $v$ cenách akcií na trhu ve Frankfurtu se zpožděním 40 minut až 1 hodina. Obdobně reagují dva relativně malé akciové trhy v Praze $a$ Varšavě na informaci obsaženou v cenách akcií na trhu ve Frankfurtu. Reakce pražského trhu odehrávající se během 30 minut je rychlejší než reakce varšavského trhu, kde je detekováno zpožděním okolo 1 hodiny.
\end{abstract}

Keywords: Stock market integration, Market comovement, High-frequency data, Speed of information transmission, Cointegration, Granger causality

JEL Classification: G14, G15

\footnotetext{
${ }^{1}$ CERGE-EI, a joint workplace of Charles University and the Academy of Sciences of the Czech Republic, Prague. Correspondence to: CERGE-EI, Politickych veznu 7, 11112 Prague, Czech Republic. E-mail: Alexandr.Cerny@cergeei.cz.

This work was supported by the Grant Agency of the Czech Republic, project 402/04/0270. The author would like to thank Dagmar Parizkova and Bloomberg, Prague, for providing the data for this research and Michal Koblas from the Czech National Bank for assistance with downloading the data.
} 


\section{Introduction}

Increasing globalization of the world economy should obviously have an impact on the behavior of national stock markets. The relaxation of all types of economic barriers and developments in information technologies are, among others, expected to induce stronger stock market integration as opposed to stock market fragmentation. With integrated stock markets, information originating from one market should be important to other markets. This assumption has motivated an intensive area of empirical research on the transmission of information across equity markets.

Using a rough criterion, this research can be divided into two areas. The first area studies stock market integration and focuses on statistical relationships between the indices from different markets, typically using cointegration or Granger causality analysis, e.g., Huang and Fok (2001); Seabra (2001); Dickinson (2000); Bracker et al. (1999); Chelley-Steeley et al. (1998); Richards (1996); or Chou et al. (1994). The second area focuses on the effect of macroeconomic releases from different countries on different markets. It studies the impact of the releases on market returns, volatility, and trading volumes. Papers from this area include, for example, Andersen et al. (2003); Connolly and Wang (2003); Wongswan (2003); and Ehrmann and Fratzscher (2002).

In this paper I address the problem of stock market integration as the first area of research does, but employ high frequency data characteristic for the second research area. So far, cointegration and Granger causality tests between stock market indices were performed with daily or even lower data frequencies ${ }^{2}$. The reason for this might be that historical high frequency data on indices from most stock markets are not easily available. Studies of the reaction of stock markets to macroeconomic releases employ typically high frequency index data only from the markets in the U.S. and London, using FTSE 100 futures as a proxy for the spot index. Nevertheless, these studies suggest that the markets react to macroeconomic releases very quickly, faster than within one hour. Therefore, there are good reasons to believe that also the reaction of stock markets to the information revealed in prices on other stock markets should be 
very fast. The use of daily data in cointegration and Granger causality tests would be then quite misleading.

If the reaction of prices on a market $A$ to the information revealed in prices on a market $B$ occurs faster than within one day, then we should not detect cointegration or Granger causality with daily data. With the use of daily data, the markets would appear informationally efficient. Informational efficiency means in this case that today's expectation of tomorrow's return on market $\mathrm{A}$, conditional on the available information, equals today's return on market A. However, cointegration and Granger causality would imply that we could improve the expectation of tomorrow's return on market $\mathrm{A}$ using the information about today's return on market $\mathrm{B}$. On the other hand, we should detect cointegration and Granger causality among indices from two markets when using data of a frequency close to the speed of information transmission between the two markets. When further increasing the data frequency, cointegration and Granger causality should disappear once the data are collected at intervals much lower than is the time needed for information transmission between the two markets. With such high frequency data, the markets would appear as completely independent.

The arguments presented above suggest that data frequency should play an important role for cointegration and Granger causality tests among indices from different stock markets. Therefore, I perform cointegration and Granger causality tests with data of different frequencies. I use a unique dataset covering eight months of high frequency data on the indices from the markets in the U.S., London, Frankfurt, Paris, Warsaw, and Prague. This allows me to vary the data frequency from 5 minutes to one day. My aim is to uncover the time structure of the reaction of prices on one market to the information revealed in prices on other markets. Particularly I am interested in the speed at which the information is transmitted between the markets.

I am aware that I cannot directly address the nature of the information transmission. My tests cannot distinguish if the information revealed in the prices on one market is transmitted directly to the prices on another market or if the two markets react to some other relevant

\footnotetext{
${ }^{2}$ The term frequency is actually used incorrectly in this area of research. When I say daily frequency of the data, I mean, in fact, a daily period. With higher frequencies, like hourly or 30 minutes frequencies, I mean data collected
} 
information about economic fundamentals (like macroeconomic releases could be) in a similar manner but at slightly different speeds. In other words, I do not address the question of contagion between markets versus reaction to economic fundamentals.

\section{Data Description}

The data employed in this paper were provided free of charge by Bloomberg, Prague. I use five minute interval data on stock market indices from the markets in the U.S., London, Frankfurt, Paris, Warsaw, and Prague. The individual indices are: S\&P 500 and Dow Jones Industrial Average (U.S.), FTSE 100 (London), DAX 30 (Frankfurt), CAC 40 (Paris), WIG 20 (Warsaw), and PX 50 (Prague). It is not possible to obtain historical 5 minute interval data on all these indices. The data are stored in the Bloomberg database only for the last month. Therefore, the data were downloaded eight times during eight months so that a time span starting on June 2, 2003, at 13:30 and ending on February 12, 2004, at 13:00 West and Central European Daylight Time was covered. ${ }^{3}$

Table 1 shows the time periods for which the data are mostly available each trading day for each individual index. Table 2 shows basic summary statistics on the natural logarithms of the indices and on the associated logarithmic five minute returns (five minute logarithmic differences).

Table 1: Daily time periods of available data on individual indices.

\begin{tabular}{lcc}
\hline \hline & From & Time period \\
Index & $15: 30$ & To \\
\hline S\&P 500 & $15: 30$ & $22: 00$ \\
DJIA & $9: 00$ & $22: 10$ \\
FTSE 100 & $9: 00$ & $17: 25$ \\
DAX 30 & $9: 05$ & $17: 25$ \\
CAC 40 & $10: 05$ & $15: 55$ \\
WIG 20 & $9: 30$ & $16: 00$ \\
PX 50 &
\end{tabular}

Notes: Time is given in West and Central European Daylight Time.

hourly or in 30 minute intervals.

${ }^{3}$ West and Central European Daylight Time is equal to GMT+1:00 but observes daylight saving time for the period from March 28 to October 31 , during which it is equal to GMT+2:00. 
Table 2: Statistics on logarithms of indices and five minute logarithmic returns.

\begin{tabular}{lcrrrrrrrrr}
\hline \hline & \multicolumn{4}{c}{ Logarithms of indexes } & \multicolumn{4}{c}{ Logarithmic 5 minute returns } \\
Index & Obs. & Mean & Std.Dev. & Min. & Max. & Obs. & Mean & Std.Dev. & Min. & Max. \\
\hline S\&P 500 & 14219 & 6.95 & 0.049 & 6.87 & 7.05 & 14036 & $9.08 \mathrm{E}-6$ & $8.05 \mathrm{E}-4$ & -0.007 & 0.007 \\
DJIA & 13854 & 9.18 & 0.051 & 9.09 & 9.28 & 13673 & $1.03 \mathrm{E}-5$ & $8.11 \mathrm{E}-4$ & -0.007 & 0.007 \\
FTSE 100 & 17972 & 8.36 & 0.032 & 8.28 & 8.42 & 17745 & $-7.28 \mathrm{E}-6$ & $6.14 \mathrm{E}-4$ & -0.005 & 0.004 \\
DAX 30 & 21943 & 8.18 & 0.080 & 8.01 & 8.34 & 21762 & $8.85 \mathrm{E}-6$ & $11.1 \mathrm{E}-4$ & -0.019 & 0.012 \\
CAC 40 & 18144 & 8.11 & 0.054 & 8.01 & 8.22 & 17959 & $2.26 \mathrm{E}-6$ & $9.05 \mathrm{E}-4$ & -0.008 & 0.005 \\
WIG 20 & 12455 & 7.31 & 0.100 & 7.08 & 7.46 & 12273 & $10.4 \mathrm{E}-6$ & $15.3 \mathrm{E}-4$ & -0.012 & 0.019 \\
PX 50 & 13118 & 6.42 & 0.079 & 6.27 & 6.62 & 12630 & $19.6 \mathrm{E}-6$ & $5.99 \mathrm{E}-4$ & -0.009 & 0.008 \\
\hline \hline
\end{tabular}

\section{Methodology}

To test for Granger causality and cointegration, I use the standard methodology proposed by Granger (1969, 1986) and Engle and Granger (1987) as described in Enders (1995). All tests are performed on natural logarithms of the indices' time series using simple OLS estimation procedures. $^{4}$

\subsection{Granger Causality and Cointegration Tests}

In order to test for Granger causality among stock market indices $x_{t}$ and $y_{t}, I$ estimate the equation

$$
\Delta \ln y_{t}=c+\sum_{i=1}^{K} \alpha_{i} \Delta \ln y_{t-i}+\sum_{i=1}^{K} \beta_{i} \Delta \ln x_{t-i}+\varepsilon_{t}
$$

and perform an $\mathrm{F}$ test for joint insignificance of the coefficients $\beta_{\mathrm{i}}, i=1 \ldots K$. The null hypothesis claims that $x_{t}$ does not Granger cause $y_{t}$. Therefore, the rejection of the null hypothesis indicates a presence of Granger causality. For each pair of stock market indices, I can perform two Granger causality tests so that I can decide whether $x_{t}$ Granger causes $y_{t}$, or $y_{t}$ Granger causes $x_{t}$, or both, or none.

When testing for cointegration of a pair of stock market indices $x_{t}$ and $y_{t}, I$ have to first determine if the logarithms of both indices are integrated of the order 1 , denoted as $I(1)^{5}$. It

\footnotetext{
${ }^{4}$ The results do not change significantly when OLS with a correction for heteroscedasticity is employed.

${ }^{5}$ I shall mention here that a simple random walk, like stochastic time series models of a stock price (and thus also of a stock market index), implies that the logarithms of the stock price contain a unit root and its differences (logarithmic returns) are stationary. This result is also predominantly confirmed in many previous studies.
} 
means that the levels of the series' logarithms must be non-stationary (contain a unit root) and the differences must already be stationary. To test for stationarity, I employ the standard augmented Dickey-Fuller test (ADF test). For levels I estimate equation (2) and for differences equation (3):

$$
\begin{aligned}
& \ln y_{t}=c+\beta t+\delta \ln y_{t-1}+\sum_{i=1}^{K} \alpha_{i} \Delta \ln y_{t-i}+\varepsilon_{t}, \\
& \Delta \ln y_{t}=c+\delta \Delta \ln y_{t-1}+\sum_{i=1}^{K} \alpha_{i} \Delta^{2} \ln y_{t-i}+\varepsilon_{t} .
\end{aligned}
$$

It means that I allow the levels to contain a constant term and a linear time trend, whereas for the differences I include only a constant term in the estimated equation. Under the null hypothesis of the presence of a unit root (non-stationarity), the test statistic defined as the t-ratio of $(\delta-1)$ equals zero, that is $(\delta-1) / \mathrm{Se}(\delta)=0$. To test this hypothesis, I compare the test statistic to the finite sample critical values tabulated by Cheung and Lai (1995). If the test statistic is lower than the appropriate critical value, then I reject the null hypothesis and decide that the time series is stationary. Otherwise, I regard the series as non-stationary (containing a unit root).

If the logarithms of both series $x_{t}$ and $y_{t}$ are found to be I(1), then I proceed to the test of cointegration. I estimate a simple linear relationship between the two time series defined by equations (4) or (5):

$$
\begin{aligned}
& \ln y_{t}=c+\alpha \ln x_{t}+\varepsilon_{t}, \\
& \ln x_{t}=c+\alpha \ln y_{t}+\varepsilon_{t} .
\end{aligned}
$$

Then I apply the ADF test to the estimated residuals $e_{t}$ from each of the two equations (4) or (5). It means that I estimate the equation

$$
e_{t}=\delta e_{t-1}+\sum_{i=1}^{K} \alpha_{i} \Delta e_{t-i}+\varepsilon_{t} .
$$

In this case I do not even allow for a constant in equation (6) because $e_{t}$ is a series of regressions' residuals. Further, I proceed as with the ADF test applied on levels and differences of the logarithms of stock market indices. I compute the test statistic $(\delta-1) / S e(\delta)$ and compare it 
to the finite sample critical values tabulated by MacKinnon (1991). If the test statistic is lower than the appropriate critical value, then I reject the null hypothesis and decide that the time series of the residuals $e_{t}$ is stationary. In this case I claim that the stock market indices $x_{t}$ and $y_{t}$ are cointegrated. Otherwise, the residuals $e_{t}$ are regarded as non-stationary and no cointegration relationship is detected.

Cointegration between the indices $x_{t}$ and $y_{t}$ indicates the presence of a long run equilibrium relationship represented by the equation (4) or (5). If one index deviates from this relationship in a period $t$, then it tends to return back to it in the following periods. As a result none of the indices should depart too far from this equilibrium. This idea is mathematically expressed with an error correction model that can be estimated using the following equations:

$$
\begin{aligned}
& \Delta \ln y_{t}=c_{1}+\delta_{1} e_{t-1}+\sum_{i=1}^{K} \alpha_{1 i} \Delta \ln y_{t-i}+\sum_{i=1}^{K} \beta_{1 i} \Delta \ln x_{t-i}+\varepsilon_{t}, \\
& \Delta \ln x_{t}=c_{2}+\delta_{2} e_{t-1}+\sum_{i=1}^{K} \alpha_{2 i} \Delta \ln y_{t-i}+\sum_{i=1}^{K} \beta_{2 i} \Delta \ln x_{t-i}+\varepsilon_{t},
\end{aligned}
$$

where $e_{t}$ are the estimated residuals from equations (4) or (5). If the indices $x_{t}$ and $y_{t}$ are found cointegrated, then at least one of the coefficients $\delta_{1}$ and $\delta_{2}$ should appear significant in the estimated equations (7) and (8) and its sign should be such that the deviation from the long run equilibrium in period $t-1$ ( $e_{t-1}$ is used as a proxy for this deviation) will be corrected in the following period $t$.

In the tests described above, sums of lagged differences are included in the estimated equations (1), (2), (3), (6), (7), and (8). The lagged differences control for potential serial autocorrelation in residuals. To select the highest lag $K, I$ use a modification of the nonparametric method presented by Campbell and Perron (1991), and $\mathrm{Ng}$ and Perron (1995). The number of lags $K$ is initially set at the maximum value 8 and the statistical significance of the coefficient on the highest lag is checked using a simple t-test. If it is insignificant at the $10 \%$ level, the number of lags is reduced by one and the procedure is repeated until statistical significance of the coefficient by the highest lag is achieved. If lagged differences for two variables are included (as in equations (1), (7), and (8), then I include the same number of 
lagged differences for both of them. Therefore, $K$ is set when at least one of the coefficients on the highest lag is significant at the $10 \%$ level of significance.

\subsection{Tests with Different Data Frequencies}

The major goal of this paper is to compare the results of Granger causality and cointegration tests for different data frequencies. Namely, I perform the tests with the stock market index data of the following frequencies: 5 minutes, 10 minutes, 20 minutes, 30 minutes, 40 minutes, 50 minutes, 1 hour, and 1 day. To assure comparability of the results with different data frequencies, I proceed in the following way. For each pair of the tested indices I choose one time and select the available daily observations only for this particular time. The chosen times are 21:50 for a pair of U.S. indices, 15:40 for a pair of European indices, and 17:15 for a pair consisting of one U.S. and one European index. All the times are expressed in West and Central European Daylight Time. With such 'daily' time series, I use different lags for the tests with different frequencies. For example, when performing Granger causality tests on 5 minute interval data I employ 5 minute lags in the equation (1), with 10 minute interval data I employ 10 minute lags, etc. With daily frequency data, I do not control for any potential Monday effects and take Friday as the directly preceding day. The times $21: 50,15: 40$, and 17:15 are chosen so that enough lags on all frequencies are available for both indices in the pair. Simultaneously, I avoid the closing times of any of the markets to prevent some potential special properties of the closing time index values from influencing the results. Nevertheless, the maximum number of lags allowed in the estimated equations is lower than 8 as the frequencies approach 1 hour (see Table 3 below in Results).

Depending on each individual pair of indices, the number of observations employed in the tests ranges between 150 and 177 for frequencies up to 1 hour, with a typical value around 170 . For the tests with daily frequency the number of observations ranges between 105 and 167 . 


\section{Results}

The results of all Granger causality tests, cointegration tests, and error correction model estimations are given in Tables 5, 6, and 7 in the Appendix. I performed Granger causality and cointegration tests with different frequencies of the following nine pairs of stock market indices: DJIA and S\&P 500, S\&P 500 and FTSE 100, S\&P 500 and DAX 30, FTSE 100 and DAX 30, FTSE 100 and CAC 40, DAX 30 and CAC 40, DAX 30 and WIG 20, DAX 30 and PX 50, WIG 20 and PX 50.

The first pair of the two indices from the U.S. stock markets is used as a benchmark. DJIA and S\&P 500 are two indexes covering stock markets in the same country. Therefore, Granger causality or cointegration relationships should occur only at very high frequencies because the transmission of information should be very fast. Unfortunately, the two indices do not measure the performance of two non-intersecting sets of stocks. In fact, the DJIA can be viewed as a 'subset' of the S\&P 500. All 30 DJIA index components are among the 500 stocks, whose prices are used to compute the value of the S\&P 500 index (this held at least throughout the time span investigated in this paper). For example, in August 2004, the weight of the 30 DJIA index components in the S\&P 500 index was around 35\%. This weight can slightly change over time due to the S\&P500 index weighting scheme. While the DJIA is calculated on a price-weighted basis, the S\&P 500 components are weighted proportionally to the market capitalization of the corresponding companies. Therefore, it is not possible to compute that part of the S\&P 500 index measuring the remaining 470 stocks not included in the DJIA, unless we know the exact market capitalization of all the S\&P 500 components at any point in time. The 'overlap' of the two indices could cause a slight bias in the results of this paper. The bias should lead towards not detecting any Granger causality, because any time series will never Granger cause itself. In the case of cointegration, the bias should lead towards finding a cointegration relationship because any time series is trivially cointegrated with itself, as the residuals from the regressions (4) or (5) equal zero. However, any of the two biases should not be too serious, because about two thirds of the S\&P 500 index is calculated using prices of the 470 stocks not included in the DJIA. Nevertheless, it should be mentioned that any of the 470 companies whose stocks are 
not included in the DJIA index has a much lower market capitalization than any of the 30 companies whose stocks are included in both indexes. Thus, when using DJIA and S\&P 500 indices in Granger causality and cointegration analysis in this paper, we in fact investigate the transmission of information revealed in prices of large (represented by the DJIA) and relatively small U.S. companies (represented by S\&P 500).

The second and third pair investigate the relationships between the U.S. S\&P 500 index and the two major European indices of the markets in London (FTSE 100) and Frankfurt (DAX 30). The next three pairs include three European indices: FTSE 100, DAX 30, and CAC 40 of the stock market in Paris. The next two pairs study the relationships between DAX 30 and two indexes from relatively small and still emerging Eastern European markets in Warsaw (WIG 20) and Prague (PX 50). The last pair includes the two emerging markets indices WIG 20 and PX 50.

Table 3: Maximum number of lags available in Granger causality and cointegration tests for each pair of indices and different data frequencies.

\begin{tabular}{|c|c|c|c|c|c|c|c|c|}
\hline \multirow{2}{*}{$\begin{array}{l}\text { Indices } \\
\text { pair }\end{array}$} & \multicolumn{8}{|c|}{ Frequency } \\
\hline & $5 \mathrm{~min}$ & $10 \mathrm{~min}$ & $20 \mathrm{~min}$ & $30 \mathrm{~min}$ & $40 \mathrm{~min}$ & $50 \mathrm{~min}$ & 1 hour & 1 day \\
\hline DJIA and S\&P & 8 & 8 & 8 & 8 & 8 & 6 & 5 & 8 \\
\hline S\&P and FTSE & 8 & 8 & 4 & 2 & 1 & 1 & 0 & 8 \\
\hline S\&P and DAX & 8 & 8 & 4 & 2 & 1 & 1 & 0 & 8 \\
\hline FTSE and DAX & 8 & 8 & 8 & 8 & 8 & 7 & 5 & 8 \\
\hline FTSE and CAC & 8 & 8 & 8 & 8 & 8 & 6 & 5 & 8 \\
\hline DAX and CAC & 8 & 8 & 8 & 8 & 8 & 6 & 5 & 8 \\
\hline DAX and WIG & 8 & 8 & 8 & 8 & 7 & 6 & 5 & 8 \\
\hline DAX and PX & 8 & 8 & 8 & 8 & 8 & 6 & 5 & 8 \\
\hline WIG and PX & 8 & 8 & 8 & 8 & 7 & 5 & 4 & 8 \\
\hline
\end{tabular}

If possible, I allow for a maximum of 8 lags of the logarithmic differences in all the performed tests. However, the number of available lags is lower for data frequencies close to 1 hour. The maximum number of available lags in Granger causality and cointegration tests for different frequencies with each pair of indices is given in Table 3. The problem of a low number of available lags becomes the most serious in the case of the following two pairs: S\&P 500 with FTSE 100 and S\&P 500 with DAX 30. Here, the number of available lags drops to 2 for 30 minute frequencies and to 1 for 40 and 50 minute frequencies. With hourly data the tests cannot 
be performed at all because zero lags are available. Therefore, the results of the tests for these two indices' pairs cannot be viewed as fully comparable to the results with the other pairs.

I should be also careful when comparing the test results from daily data to the results from data of other frequencies. With daily data the number of available observations is lower than with other frequencies. Moreover, I do not control for any possible Monday effects and regard Fridays as directly preceding Mondays.

\subsection{Order of Integration}

First I should look at the assessed orders of integration of individual stock market indices' time series with different frequencies. These results are summarized in Table 5 in the Appendix. Note that for different pairs of indices I use different observations. Therefore, the results for one index could differ depending on the other index included in the pair. In line with the previous empirical research and with the theoretical stochastic models of stock prices, most of the indices are found to be I(1) at any frequency and using any significance level in the tests. However, with some indices I find systematic deviations from this rule. These cases are listed below.

Particularly strange are the results from the FTSE 100 index when used in a pair with other European indices (daily observations at 17:15). With 5 minute frequency data, FTSE 100 is found to be stationary at the $10 \%$ significance level both in levels and differences, which would indicate integration of the order 0 . However, with $5 \%$ and $1 \%$ significance levels, I should interpret it as non-stationary both in levels and differences, which would mean that it is integrated at an order higher than 1 . With 40 minute frequency data it can be interpreted as I(1) only at the $5 \%$ and $1 \%$ levels of significance, and with 50 minute and daily frequencies, only at the $1 \%$ significance level. I do not have any explanation for this strange behavior. It becomes even more surprising if we look at the FTSE 100 index order of integration results for a pair with the U.S. S\&P 500 index (daily observations at 15:40). Here, I get the standard result for all frequencies - I(1) at any significance level.

The DAX 30 index used in any pair with other European indices seems to be non-stationary both in levels and differences with 5 minute frequency data, which indicates integration of an 
order higher than 1. On the other hand, with daily frequency and in any pair, it is found to be stationary already at the $10 \%$ significance level. Nevertheless, at the $5 \%$ and $1 \%$ significance levels, it appears to be I(1), as we would expect.

The CAC 40 index is tested as I(0) (already stationary in levels) with daily frequency at the $5 \%$ significance level when used in the pair with the FTSE 100 and DAX 30 indices. Nevertheless, at the $1 \%$ significance level, it can be interpreted as $I(1)$.

Finally, the last deviation from the standard I(1) rule is detected with the WIG 20 and PX 50 indices and with 20 and 30 minutes frequencies. WIG 20 seems to be integrated of an order higher than 1 at both of these frequencies in the pair with the DAX 30 index and at a frequency of 30 minutes only in the pair with the PX 50 index. PX 50 appears to be integrated of an order higher than 1 at a frequency of 30 minutes in the pair with the DAX 30 index and at both 20 and 30 minutes frequencies when used in the pair with WIG 20.

\subsection{Cointegration}

The results of cointegration are given in Table 5 in the Appendix. Cointegration of two time series represents a fairly strong relationship. It implies the existence of a long run equilibrium, towards which the two time series tend to converge. It also implies that the two time series must share a common stochastic trend. Moreover, cointegration tests are based on the ADF test, which is known to have a low power. This means that even if the two time series are cointegrated in reality, the ADF test is quite likely to not detect this relationship. This is particularly true when we do not have a sufficiently large number of observations, which is to some extent the case.

Therefore, it is not surprising that cointegration is detected only rarely in the data. At the $5 \%$ significance level, cointegration is detected only for the pair of FTSE 100 and CAC 40 indexes with frequencies ranging from 10 minutes to 1 hour (here even at the $1 \%$ significance level) and for the pair FTSE 100 and DAX 30 with frequencies of 40 and 50 minutes. However, when looking at the problematic order of integration results with the FTSE 100 index, I can regard as credible only the cointegration of the pair FTSE 100 and CAC 40 with the frequency of 1 hour. 
Only the cointegration with hourly data is supported with the error correction model (see Table 6 in the Appendix). Nevertheless, I refrain from any interpretation of this result because it is unique in my set of tests and cannot be compared to similar results with the other pairs of stock market indices.

\subsection{Granger Causality}

The results of Granger causality tests given in Table 7 in the Appendix have a richer structure than those of cointegration. Table 4 below summarizes these results for each pair of indices and each data frequency.

Table 4: Results of Granger causality tests with different data frequencies.

\begin{tabular}{|c|c|c|c|c|c|c|c|c|}
\hline & & & & Freq & ency & & & \\
\hline $\mathbf{G C} \rightarrow$ & $5 \min$ & $10 \mathrm{~min}$ & $20 \mathrm{~min}$ & $30 \mathrm{~min}$ & $40 \mathrm{~min}$ & $50 \mathrm{~min}$ & 1 hour & 1 day \\
\hline$S \& P \rightarrow D J I A$ & & & & & & & & \\
\hline S\&P $\rightarrow$ S\&P & & W & 関 & & & & & \\
\hline FTSE $\rightarrow$ S\&P & & & & & & & & \\
\hline$S \& P \rightarrow D A X$ & & & & 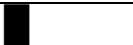 & & & & \\
\hline $\mathrm{DAX} \rightarrow S \& P$ & & & & & & & & \\
\hline FTSE $\rightarrow$ DAX & & & 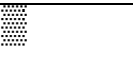 & & & & & \\
\hline DAX $\rightarrow$ FTSE & & & & & & & & \\
\hline FTSE $\rightarrow$ CAC & & & & & & & & \\
\hline $\mathrm{DAX} \rightarrow \mathrm{CAC}$ & & & III & 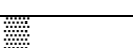 & & 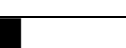 & & \\
\hline $\mathrm{CAC} \rightarrow \mathrm{DAX}$ & & & 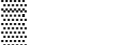 & & & & & \\
\hline $\mathrm{DAX} \rightarrow \mathrm{WIG}$ & & & & & & & & \\
\hline WIG $\rightarrow \mathrm{DAX}$ & & & & & & & & \\
\hline $\mathrm{DAX} \rightarrow \mathrm{PX}$ & & & 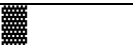 & & & & & \\
\hline $\mathrm{PX} \rightarrow \mathrm{DAX}$ & & & & & & & & \\
\hline $\mathrm{WIG} \rightarrow \mathrm{PX}$ & & & Wa & 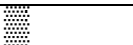 & & & & \\
\hline $\mathrm{PX} \rightarrow \mathrm{WIG}$ & & & 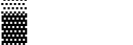 & & & & & \\
\hline
\end{tabular}

First, let me look at Granger causality between the two U.S. stock market indices: S\&P 500 and DJIA. This pair can serve as a benchmark because the two indices are from markets in the same country. In line with this fact I detect Granger causality only with the highest 5 minute frequency data and only at significance levels of $10 \%$ in one case (S\&P 500 GC DJIA) and 5\% in the other case (DJIA GC S\&P 500). It means that the two indexes either react very quickly to 
each other, or react to information relevant for the U.S. stock markets almost equally fast and in a similar manner. Surprisingly, my results also suggest that DJIA Granger causes S\&P 500 with daily data frequency. Similarly, I find that the Frankfurt index DAX 30 Granger causes S\&P 500 with daily frequency. The reason for this might be the large diversification of the S\&P 500 index. It is the most diversified index used in this paper. As already mentioned above it also reflects the prices of stocks of relatively smaller companies (particularly when compared to the DJIA). It can be the case that the prices of stocks of these smaller companies, which are potentially also less liquid, react slower to the relevant information. However, this result could be also misleading because with daily frequency I use only 121 observations, while with other frequencies the number of observations exceeds 170.

Second, I consider Granger causality between the S\&P 500 index and the two major European indices FTSE 100 and DAX 30. Here, we see a different pattern than with the two U.S. indices above. S\&P 500 seems to Granger cause FTSE 100 and DAX 30 with 5 minute and 30 minute frequency data (even at the $1 \%$ significance level in the case of DAX 30 ). The opposite Granger causality relationship is detected only at the $5 \%$ significance level with the DAX 30 index, which seems to Granger cause S\&P 500 with 10 minute and daily frequency data. Granger causality with daily frequency data could reflect the large diversification of the S\&P 500 index. However, as already mentioned above, the result with daily frequency data must be viewed with caution because fewer observations are available here. Therefore, I conclude here that the two major European stock markets react to the information from the stock markets in the U.S. approximately within 30 minutes after this information is reflected in the S\&P 500 index. However, the first reaction occurs very quickly, approximately within the first 5 minutes. The evidence for an opposite reaction of the S\&P 500 index to the information revealed in the European indices is weak.

Third, I analyze Granger causality results between different pairs of the three European stock market indices, FTSE 100, DAX 30, and CAC 40. In this group Granger causality is detected with frequencies ranging from 10 minutes to 1 hour. With the pair FTSE 100 and CAC 40, I find only one Granger causality relationship: FTSE 100 Granger causes CAC 40 with hourly frequency data. With the pair FTSE 100 and DAX 30, FTSE 100 is found to Granger 
cause DAX 30 with frequencies of 10 and 20 minutes and 1 hour but only at the $10 \%$ significance level. DAX 30, on the other hand, Granger causes FTSE 100 with 50 minute frequency data at the $5 \%$ level of significance. The richest pattern of Granger causality relationships is detected between the DAX 30 and CAC 40 indices, with the strongest results at the $1 \%$ significance level for DAX 30 to Granger cause CAC 40 with 40 minute, 50 minute, and hourly frequencies. Further, at the $10 \%$ significance level, DAX 30 is also found to Granger cause CAC 40 with frequencies from 10 to 30 minutes. The opposite relationship of CAC 40 Granger causing DAX 30 is present with 10 minute, 20 minute, 40 minute, and hourly frequencies, but only at the $5 \%$ and $10 \%$ significance levels. I conclude that the three European markets react to the information revealed on these markets approximately within 1 hour, with the first reaction occurring already after approximately 10 minutes. There seems to be much more information flow between the two continental markets in Frankfurt and Paris than between the market in London and any of the two continental markets. The market in Paris seems to predominantly react to the information revealed on the markets in Frankfurt and London, rather than vice versa.

Fourth, I look at the results of Granger causality between the Frankfurt index DAX 30 and the two indexes from the relatively small Eastern European stock markets in Warsaw (WIG 20) and Prague (PX 50). I find strong evidence that the DAX 30 index Granger causes the WIG 20 and PX 50 indices, but there is little evidence of an opposite relationship. First a Granger causality relationship is detected with 10 minute frequency data in both cases. However, in the case of WIG 20, the strongest Granger causality occurs with 40 minute, 50 minute and 1 hour frequencies, while with the PX 50 index, strong Granger causality is detected only with 10,20 , and 30 minute frequencies. I conclude that the two small markets react to the information revealed on the market in Frankfurt and not vice versa. The stock market in Warsaw seems to react more slowly than the market in Prague, but in both cases the information is transmitted within approximately 1 hour. Thus, the speed of the reaction of these markets is comparable to that between the major European markets. This finding partly contradicts the results of various studies that investigate informational efficiency and various types of information transmission with the emerging Eastern European markets, e.g., Hanousek and Filer (2000) or Podpiera 
(2000 and 2001). These studies find typically little evidence for informational efficiency of these markets and are in this sense particularly skeptical about the stock market in Prague.

Finally, I consider Granger causality between the indices from the two markets in Warsaw and Prague (WIG 20 and PX 50). With these two indexes I detect Granger causality with 20, 30, and 50 minute and 1 hour frequencies. More evidence is presented for the PX 50 index Granger causing the WIG 20 index. However, I should be cautious to suggest that the information revealed in the Prague PX 50 index is important to the market in Warsaw. The Granger causality detected here could be a by-product of the different speeds of reaction of these two indexes to the changes in the Frankfurt DAX 30 index, as reported above. If the PX 50 index reacts to the changes in the DAX 30 index faster than the WIG 20 index, then it can spuriously Granger cause the WIG 20 index.

\section{Conclusion}

Using a dataset covering 8 months of high frequency data, I investigate the issue of stock market integration from a novel perspective. I perform cointegration and Granger causality tests with data of different frequencies. My aim is to describe the time structure in which markets react to the information revealed in prices on other markets. Particularly, I want to detect the speed of information transmission between the different markets.

I employ the indices from the U.S. stock markets (S\&P 500 and Dow Jones Industrial Average), London (FTSE 100), Frankfurt (DAX 30), Paris (CAC 40), Warsaw (WIG 20), and Prague (PX 50). The tests are performed for nine different pairs of indices using data of 5,10 , $20,30,40,50$ minute, 1 hour, and daily frequencies.

Cointegration is detected only in one case, for the pair of the FTSE 100 and CAC 40 indices with the frequency of 1 hour. However, the results of cointegration should be interpreted with caution here because the number of observations used in my tests is fairly small (around 170) and because the ADF tests employed in the cointegration analysis are known to have a low power, particularly in small data samples. 
The results of Granger causality tests are more interesting. According to these tests the markets seem to react very quickly to the information revealed in the prices on other markets. In all cases the reaction occurs as soon as within 1 hour. The U.S. markets seem to be an important source of information for the markets in London and Frankfurt; they react to it within 30 minutes, with the first reaction occurring already in five minutes. Granger causality with the London FTSE 100 index in a pair with the Parisian CAC 40 index and the Frankfurt DAX 30 index is much weaker than for the pair DAX 30 and CAC 40. The stock market in Paris seems to react to the information revealed at the stock market in Frankfurt with a delay of 40 minutes to 1 hour. Similarly, the two relatively small Eastern European markets in Warsaw and Prague are found to react to the information revealed in the stock market prices in Frankfurt. The reaction of the market in Prague seems to be faster, occurring within 30 minutes, while reaction speed of the market in Warsaw is around 1 hour.

I am aware that the results presented here are preliminary. For better understanding of the process of information transmission between the studied stock markets, in future research I will try to increase the time span of my data to at least one year. When interpreting the results, I have also neglected the differences in institutional arrangements of each of the stock markets considered in this paper. However, these differences should not significantly alter the interpretation of the results. The aim of each stock market is to have a fast, efficient, and transparent trading system that helps to quickly reveal undistorted stock prices. Thus, when investigating the information transmission, slight differences in institutional arrangements on the different markets should not matter too much. ${ }^{6}$

\footnotetext{
${ }^{6}$ To get a detailed description of the trading systems on each of the markets and for each of the stocks included in the investigated indices would be almost impossible. Some of the indices might contain stocks that are traded using different systems on the same market. Moreover, the U.S. indices S\&P 500 and DJIA contain stocks that are traded on different markets.
} 


\section{References:}

Andersen, T.G., Bellerslev, T., Diebold, F.X., Vega, C., "Real-Time Price Discovery in Stock, Bond and Foreign Exchange Markets," July 2003, www.ssb.rochester.edu.

Bracker, K., Docking, D.S., Koch P.D., „Economic Determinants of Evolution in International Stock Market Integration," Journal of Empirical Finance, 6, 1999, 1-27.

Campbell, J.Y., Perron, P., "Pitfalls and Opportunities: What Macroeconomists Should Know about Unit Roots," NBER Working Paper Series, Technical Working Paper 100,1991.

Chelley-Steeley, P.L., Steeley, J.M., Pentecost, E.J., "Exchange Controls and European Stock Market Integration," Applied Economics, 30, 1998, 263-267.

Cheung, Y-W., Lai, K.S., "Lag Order and Critical Values for the Augmented Dickey-Fuller Test," Journal of Business and Economic Statistics, 13, 1995, 277-280.

Chou, R.Y., Ng, V.K., Pi, L.K., "Cointegration of International Stock Market Indices," IMF Working Paper 94,1994.

Connolly, R.A., Wang, F.A., "International Equity Markets Comovements: Economic Fundamentals or Contagion?" Pacific-Basin Finance Journal, 11, 2003, 23-43.

Dickinson, D.G., "Stock Market Integration and Macroeconomic Fundamentals: an Empirical Analysis, 1980-95," Applied Financial Economics, 10, 2000, 261-276.

Ehrmann, M., Fratzscher, M., "Interdependence between The Euro Area and the US: What Role for EMU?" European Central Bank Working Paper 200, 2002.

Enders, W., Applied Econometric Time series, John Wiley \& Sons Inc., New York, 1995.

Engle, R.F., Granger, C.W.J., "Cointegration and Error Correction: Representation, Estimation and Testing," Econometrica, 55, 1987, 251-276.

Granger, C.W.J., "Investigating Casual Relations by Econometric Models and Cross-Spectral Methods," Econometrica, 37, 1969, 424-438.

Granger, C.W.J., "Developments in the Study of Cointegrated Economic Variables," Oxford Bulletin of Economics and Statistics, 48, 1986, 213-228.

Hanousek, J., Filer, R.K., "The Relationship between Economic Factors and Equity Markets in Central Europe," Economics of Transition, 8, 2000, 623-638.

Huang, B.N., Fok, R.C.W., "Stock Market integration - An Application of the Stochastic Permanent Breaks Model," Applied Economics Letters, 8, 2001, 1725-729.

MacKinnon, J.G., "A Critical Values for Cointegration Tests," in Long-Run Economic Relationships: Readings in Cointegration, eds. R.F. Engle and C.W.J. Granger, Oxford University Press, New York, 1991, 266-276.

Ng, S., Perron, P., "Unit Root Tests in ARMA Models with Data Dependent Methods of the Selection of the Truncation Lag," Journal of the American Statistical Association, 90, 1995, 268281.

Podpiera, R., "Efficiency of Financial Markets in Transition: The Case of Macroeconomic Releases," CERGE-EI Working Paper 156, 2000. 
Podpiera, R., "International Cross-Listing: The Effects of Market Fragmentation and Information Flows," CERGE-EI Working Paper 173, 2001.

Richards, A.J., "Comovements in National Stock Market Returns: Evidence of Predictability but not Cointegration," IMF Working Paper 28, 1996.

Seabra, F., "A cointegration Analysis Between Mercosur and International Stock Markets," Applied Economics Letters, 8, 2001, 475-478.

Wongswan, J., "Transmission of Information Across International Equity Markets," International Finance Discussion Paper 795, 2003. 


\section{Appendix}

Table 5: Results of cointegration and the order of integration tests with different data frequencies.

\begin{tabular}{|c|c|c|c|c|c|c|c|c|c|c|}
\hline \multirow{3}{*}{$\begin{array}{l}\text { Data } \\
\text { Frequency }\end{array}$} & \multicolumn{6}{|c|}{ ADF tests on residuals from } & \multicolumn{4}{|c|}{ ADF tests on levels and differences } \\
\hline & \multicolumn{3}{|c|}{$\ln y_{t}=c+\alpha \ln x_{t}+\varepsilon_{t}$} & \multicolumn{3}{|c|}{$\ln x_{t}=c+\alpha \ln y_{t}+\varepsilon_{t}$} & \multirow{2}{*}{\begin{tabular}{|l|}
$\ln x_{t}$ \\
P-value \\
\end{tabular}} & \multirow{2}{*}{$\begin{array}{l}\Delta \ln x_{t} \\
\text { P-value }\end{array}$} & \multirow{2}{*}{$\begin{array}{l}\ln y_{t} \\
\text { P-value }\end{array}$} & \multirow{2}{*}{$\frac{\Delta \ln y_{t}}{\text { P-value }}$} \\
\hline & Obs. & $K$ & P-value & Obs. & $K$ & P-value & & & & \\
\hline \multicolumn{11}{|c|}{$x_{t}=\mathrm{S} \& \mathrm{P} 500 ; y_{t}=\mathrm{DJIA}$} \\
\hline 5 minute & 172 & 1 & 0.989 & 172 & 1 & 0.993 & 1.000 & 0.000 & 0.999 & 0.001 \\
\hline 10 minute & 172 & 0 & 0.849 & 172 & 0 & 0.934 & 0.999 & 0.000 & 0.999 & 0.000 \\
\hline 20 minute & 171 & 8 & 0.822 & 171 & 8 & 0.909 & 1.000 & 0.000 & 1.000 & 0.000 \\
\hline 30 minute & 172 & 0 & 0.923 & 172 & 0 & 0.972 & 1.000 & 0.000 & 1.000 & 0.000 \\
\hline 40 minute & 172 & 0 & 0.984 & 172 & 0 & 0.995 & 1.000 & 0.000 & 0.999 & 0.000 \\
\hline 50 minute & 171 & 0 & 0.976 & 171 & 0 & 0.992 & 0.998 & 0.000 & 0.999 & 0.000 \\
\hline 1 hour & 171 & 0 & 0.996 & 171 & 0 & 0.998 & 0.998 & 0.000 & 0.999 & 0.000 \\
\hline 1 day & 120 & 6 & 0.532 & 120 & 6 & 0.641 & 0.898 & 0.000 & 0.917 & 0.000 \\
\hline \multicolumn{11}{|c|}{$x_{t}=$ S\&P $500 ; y_{t}=$ FTSE 100} \\
\hline 5 minute & 171 & 0 & 0.996 & 171 & 0 & 0.990 & 0.997 & 0.003 & 0.997 & 0.000 \\
\hline 10 minute & 170 & 4 & 0.872 & 170 & 4 & 0.915 & 0.971 & 0.000 & 0.934 & 0.000 \\
\hline 20 minute & 171 & 0 & 0.802 & 171 & 0 & 0.844 & 0.934 & 0.000 & 0.977 & 0.000 \\
\hline 30 minute & 171 & 0 & 0.861 & 171 & 1 & 0.849 & 0.984 & 0.000 & 0.942 & 0.000 \\
\hline 40 minute & 170 & 0 & 0.996 & 170 & 0 & 0.990 & 0.941 & 0.000 & 0.995 & 0.000 \\
\hline 50 minute & 171 & 0 & 0.988 & 171 & 0 & 0.971 & 0.954 & 0.000 & 0.980 & 0.074 \\
\hline \multicolumn{11}{|l|}{1 hour } \\
\hline 1 day & 116 & 6 & 0.972 & 116 & 6 & 0.979 & \begin{tabular}{|l|}
0.824 \\
\end{tabular} & 0.000 & 0.109 & 0.001 \\
\hline \multicolumn{11}{|c|}{$x_{t}=$ S\&P $500 ; y_{t}=$ DAX 30} \\
\hline 5 minute & 173 & 5 & 0.944 & 173 & 6 & 0.932 & 0.997 & 0.003 & 0.990 & 0.000 \\
\hline 10 minute & 172 & 7 & 0.958 & 172 & 4 & 0.977 & 0.971 & 0.000 & 0.380 & 0.000 \\
\hline 20 minute & 172 & 2 & 0.954 & 172 & 2 & 0.933 & 0.934 & 0.000 & 0.992 & 0.000 \\
\hline 30 minute & 173 & 1 & 0.945 & 173 & 1 & 0.876 & 0.984 & 0.000 & 0.986 & 0.000 \\
\hline 40 minute & 172 & 0 & 0.881 & 172 & 0 & 0.596 & 0.941 & 0.000 & 0.993 & 0.000 \\
\hline 50 minute & 173 & 0 & 0.297 & 173 & 0 & 0.113 & 0.954 & 0.000 & 0.976 & 0.000 \\
\hline \multicolumn{11}{|l|}{1 hour } \\
\hline 1 day & 166 & 0 & 0.390 & 142 & 4 & 0.714 & 0.824 & 0.000 & 0.074 & 0.000 \\
\hline \multicolumn{11}{|c|}{$x_{t}=$ FTSE $100 ; y_{t}=$ DAX 30} \\
\hline 5 minute & 174 & 4 & 0.134 & 174 & 4 & 0.177 & 0.064 & 0.079 & 1.000 & 0.311 \\
\hline 10 minute & 174 & 2 & 0.071 & 174 & 2 & 0.082 & 0.111 & 0.000 & 0.998 & 0.000 \\
\hline 20 minute & 173 & 4 & 0.109 & 173 & 4 & 0.095 & 0.127 & 0.000 & 0.995 & 0.000 \\
\hline 30 minute & 174 & 0 & 0.164 & 174 & 0 & 0.081 & 0.600 & 0.000 & 0.998 & 0.000 \\
\hline 40 minute & 174 & 0 & 0.014 & 174 & 0 & 0.008 & 0.062 & 0.000 & 0.998 & 0.002 \\
\hline 50 minute & 174 & 0 & 0.025 & 174 & 0 & 0.008 & 0.032 & 0.000 & 0.999 & 0.000 \\
\hline 1 hour & 174 & 0 & 0.095 & 174 & 0 & 0.091 & 0.216 & 0.000 & 0.999 & 0.000 \\
\hline 1 day & 149 & 5 & 0.213 & 149 & 5 & 0.197 & 0.041 & 0.000 & 0.071 & 0.000 \\
\hline \multicolumn{11}{|c|}{$x_{t}=$ FTSE $100 ; y_{t}=$ CAC 40} \\
\hline 5 minute & 175 & 5 & 0.041 & 175 & 5 & 0.030 & $\begin{array}{l}0.064 \\
\end{array}$ & 0.079 & 1.000 & 0.065 \\
\hline 10 minute & 175 & 2 & 0.001 & 175 & 2 & 0.001 & 0.111 & 0.000 & 0.988 & 0.002 \\
\hline 20 minute & 175 & 4 & 0.005 & 175 & 4 & 0.005 & 0.127 & 0.000 & 0.989 & 0.000 \\
\hline 30 minute & 175 & 3 & 0.003 & 175 & 3 & 0.003 & 0.600 & 0.000 & 0.965 & 0.000 \\
\hline 40 minute & 175 & 2 & 0.000 & 175 & 2 & 0.001 & 0.062 & 0.000 & 0.785 & 0.000 \\
\hline 50 minute & 175 & 1 & 0.001 & 175 & 1 & 0.001 & 0.032 & 0.000 & 0.789 & 0.000 \\
\hline 1 hour & 175 & 1 & 0.002 & 175 & 1 & 0.004 & 0.216 & 0.000 & 0.947 & 0.000 \\
\hline 1 day & 170 & 0 & 0.576 & 170 & 0 & 0.363 & 0.041 & 0.000 & 0.016 & 0.000 \\
\hline
\end{tabular}


Table 5: Continued.

\begin{tabular}{|c|c|c|c|c|c|c|c|c|c|c|}
\hline \multirow{3}{*}{$\begin{array}{l}\text { Data } \\
\text { frequency }\end{array}$} & \multicolumn{6}{|c|}{ ADF tests on residuals from } & \multicolumn{4}{|c|}{ ADF tests on levels and differences } \\
\hline & \multicolumn{3}{|c|}{$\ln y_{t}=c+\alpha \ln x_{t}+\varepsilon_{t}$} & \multicolumn{3}{|c|}{$\ln x_{t}=c+\alpha \ln y_{t}+\varepsilon_{t}$} & \multirow{2}{*}{$\begin{array}{c}\ln x_{t} \\
\text { P-value }\end{array}$} & \multirow{2}{*}{$\begin{array}{c}\Delta \ln x_{t} \\
\text { P-value }\end{array}$} & \multirow{2}{*}{$\begin{array}{c}\ln y_{t} \\
\text { P-value }\end{array}$} & \multirow{2}{*}{$\begin{array}{c}\Delta \ln y_{t} \\
\text { P-value }\end{array}$} \\
\hline & Obs. & $K$ & P-value & Obs. & $K$ & P-value & & & & \\
\hline \multicolumn{11}{|c|}{$x_{t}=\operatorname{DAX} 30 ; y_{t}=$ CAC 40} \\
\hline 5 minute & 176 & 8 & 0.999 & 176 & 8 & 0.999 & 1.000 & 0.311 & 1.000 & 0.065 \\
\hline 10 minute & 177 & 1 & 0.996 & 177 & 1 & 0.995 & 0.998 & 0.000 & 0.988 & 0.002 \\
\hline 20 minute & 175 & 7 & 0.994 & 175 & 7 & 0.991 & 0.995 & 0.000 & 0.989 & 0.000 \\
\hline 30 minute & 177 & 0 & 0.993 & 177 & 0 & 0.996 & 0.998 & 0.000 & 0.965 & 0.000 \\
\hline 40 minute & 177 & 0 & 0.944 & 177 & 0 & 0.978 & 0.998 & 0.002 & 0.785 & 0.000 \\
\hline 50 minute & 177 & 0 & 0.976 & 177 & 0 & 0.987 & 0.999 & 0.000 & 0.789 & 0.000 \\
\hline 1 hour & 177 & 0 & 0.978 & 177 & 0 & 0.987 & 0.999 & 0.000 & 0.947 & 0.000 \\
\hline 1 day & 174 & 0 & 0.469 & 174 & 0 & 0.481 & 0.071 & 0.000 & 0.016 & 0.000 \\
\hline \multicolumn{11}{|c|}{$x_{t}=$ DAX $30 ; y_{t}=$ WIG 20} \\
\hline 5 minute & 174 & 7 & 1.000 & 174 & 3 & 1.000 & 1.000 & 0.311 & 0.999 & 0.000 \\
\hline 10 minute & 174 & 0 & 1.000 & 174 & 0 & 1.000 & 0.998 & 0.000 & 1.000 & 0.000 \\
\hline 20 minute & 174 & 0 & 0.905 & 174 & 0 & 0.944 & 0.995 & 0.000 & 0.861 & 0.189 \\
\hline 30 minute & 174 & 3 & 0.885 & 174 & 3 & 0.931 & 0.998 & 0.000 & 0.863 & 0.116 \\
\hline 40 minute & 174 & 1 & 0.920 & 174 & 1 & 0.973 & 0.998 & 0.002 & 0.681 & 0.000 \\
\hline 50 minute & 174 & 0 & 0.916 & 174 & 0 & 0.971 & 0.999 & 0.000 & 0.681 & 0.000 \\
\hline 1 hour & 174 & 0 & 0.940 & 174 & 0 & 0.972 & 0.999 & 0.000 & 0.793 & 0.000 \\
\hline 1 day & 138 & 6 & 0.371 & 168 & 0 & 0.838 & 0.071 & 0.000 & 0.664 & 0.000 \\
\hline \multicolumn{11}{|c|}{$x_{t}=\operatorname{DAX} 30 ; y_{t}=$ PX 50} \\
\hline 5 minute & 161 & 4 & 0.999 & 161 & 4 & 0.999 & 1.000 & 0.311 & 1.000 & 0.000 \\
\hline 10 minute & 152 & 8 & 0.999 & 168 & 0 & 1.000 & 0.998 & 0.000 & 0.999 & 0.000 \\
\hline 20 minute & 167 & 0 & 0.998 & 167 & 0 & 0.998 & 0.995 & 0.000 & 0.980 & 0.000 \\
\hline 30 minute & 156 & 6 & 0.997 & 156 & 6 & 0.995 & 0.998 & 0.000 & 0.949 & 0.097 \\
\hline 40 minute & 161 & 4 & 1.000 & 161 & 4 & 1.000 & 0.998 & 0.002 & 0.994 & 0.002 \\
\hline 50 minute & 104 & 6 & 1.000 & 104 & 6 & 0.997 & 0.999 & 0.000 & 0.999 & 0.001 \\
\hline 1 hour & 167 & 0 & 1.000 & 167 & 0 & 1.000 & 0.999 & 0.000 & 0.992 & 0.000 \\
\hline 1 day & 161 & 0 & 0.926 & 161 & 0 & 0.480 & 0.071 & 0.000 & 0.688 & 0.000 \\
\hline \multicolumn{11}{|c|}{$x_{t}=$ WIG 20; $y_{t}=$ PX 50} \\
\hline 5 minute & 154 & 5 & 0.999 & 154 & 5 & 0.999 & 0.999 & 0.000 & 1.000 & 0.000 \\
\hline 10 minute & 154 & 6 & 0.997 & 154 & 6 & 0.998 & 1.000 & 0.000 & 0.999 & 0.000 \\
\hline 20 minute & 159 & 5 & 0.494 & 159 & 5 & 0.333 & 0.980 & 0.000 & 0.861 & 0.189 \\
\hline 30 minute & 157 & 4 & 0.959 & 157 & 4 & 0.951 & 0.863 & 0.116 & 0.949 & 0.097 \\
\hline 40 minute & 160 & 3 & 0.980 & 160 & 3 & 0.912 & 0.681 & 0.000 & 0.994 & 0.002 \\
\hline 50 minute & 168 & 0 & 0.971 & 168 & 0 & 0.871 & 0.681 & 0.000 & 0.999 & 0.001 \\
\hline 1 hour & 163 & 2 & 0.960 & 163 & 2 & 0.896 & 0.793 & 0.000 & 0.992 & 0.000 \\
\hline 1 day & 158 & 0 & 0.873 & 158 & 0 & 0.373 & 0.664 & 0.000 & 0.688 & 0.000 \\
\hline
\end{tabular}

Notes: Obs. stand for the number of observations and $K$ for the number of lagged differences used in the ADF tests. The reported P-values indicate the ADF tests' significance levels at which the null hypothesis of non-stationarity can be rejected. Finite sample critical values are from Cheung and Lai (1995) for the ADF tests with the levels and differences of indices' logarithms and from MacKinnon (1991) for the ADF tests with the residuals. P-values other than 0.01, 0.05, and 0.10 are computed using a logistic interpolation. Such P-values are fine for testing at the common significance levels of $10 \%, 5 \%$, and $1 \%$, but rather speculative outside this range. 
Table 6: Results of the estimation of error correction models with different data frequencies.

\begin{tabular}{|c|c|c|c|c|c|c|c|c|c|c|c|c|}
\hline \multirow{5}{*}{$\begin{array}{l}\text { Data } \\
\text { frequency }\end{array}$} & \multicolumn{12}{|c|}{ Estimated equation } \\
\hline & \multirow{2}{*}{\multicolumn{6}{|c|}{$\begin{array}{c}\Delta \ln y_{t}=c_{1}+\delta_{1} e_{t-1}+\sum_{i=1}^{K} \alpha_{1 i} \Delta \ln y_{t-i}+\sum_{i=1}^{K} \beta_{1 i} \Delta \ln x_{t-i}+\varepsilon_{t} \\
\text { Residuals } \boldsymbol{e}_{t} \text { from the equation }\end{array}$}} & \multirow{2}{*}{\multicolumn{6}{|c|}{$\begin{array}{c}\Delta \ln x_{t}=c_{1}+\delta_{1} e_{t-1}+\sum_{i=1}^{K} \alpha_{1 i} \Delta \ln x_{t-i}+\sum_{i=1}^{K} \beta_{1 i} \Delta \ln y_{t-i}+\varepsilon_{t} \\
\text { Residuals } e_{t} \text { from the equation }\end{array}$}} \\
\hline & & & & & & & & & & & & \\
\hline & \multicolumn{3}{|c|}{$\ln y_{t}=c+\alpha \ln x_{t}+\varepsilon_{t}$} & \multicolumn{3}{|c|}{$\ln x_{t}=c+\alpha \ln y_{t}+\varepsilon_{t}$} & \multicolumn{3}{|c|}{$\ln y_{t}=c+\alpha \ln x_{t}+\varepsilon_{t}$} & \multicolumn{3}{|c|}{$\ln x_{t}=c+\alpha \ln y_{t}+\varepsilon_{t}$} \\
\hline & Obs. & $K$ & P-value & Obs. & $K$ & P-value & Obs. & $K$ & P-value & Obs. & $K$ & P-value \\
\hline \multicolumn{13}{|c|}{$x_{t}=$ S\&P 500; $y_{t}=$ DJIA } \\
\hline 5 minute & 172 & 5 & 0.058 & 172 & 5 & 0.058 & 172 & 5 & 0.018 & 172 & 5 & 0.440 \\
\hline 10 minute & 171 & 8 & 0.652 & 171 & 8 & 0.653 & 171 & 8 & 0.619 & 171 & 8 & 0.619 \\
\hline 20 minute & 172 & 0 & 0.620 & 172 & 0 & 0.610 & 171 & 6 & 0.892 & 171 & 6 & 0.892 \\
\hline 30 minute & 172 & 0 & 0.717 & 172 & 0 & 0.637 & 171 & 1 & 0.659 & 171 & 1 & 0.659 \\
\hline 40 minute & 172 & 1 & 0.763 & 172 & 1 & 0.763 & 172 & 1 & 0.714 & 172 & 1 & 0.714 \\
\hline 50 minute & 171 & 1 & 1.000 & 171 & 1 & 1.000 & 171 & 1 & 0.505 & 171 & 1 & 0.505 \\
\hline 1 hour & 172 & 1 & 0.917 & 172 & 1 & 0.917 & 171 & 1 & 0.460 & 171 & 1 & 0.460 \\
\hline 1 day & 121 & 1 & 0.217 & 121 & 6 & 0.217 & 113 & 7 & 0.308 & 113 & 7 & 0.308 \\
\hline \multicolumn{13}{|c|}{$x_{t}=$ S\&P 500; $y_{t}=$ FTSE 100} \\
\hline 5 minute & 171 & 6 & 0.837 & 171 & 6 & 0.493 & 170 & 7 & 0.413 & 170 & 7 & 0.422 \\
\hline 10 minute & 170 & 3 & 0.009 & 170 & 3 & 0.351 & 170 & 4 & 0.563 & 170 & 4 & 0.138 \\
\hline 20 minute & 170 & 0 & 0.363 & 170 & 0 & 0.225 & 170 & 0 & 0.255 & 170 & 0 & 0.241 \\
\hline 30 minute & 171 & 2 & 0.559 & 171 & 2 & 0.047 & 171 & 2 & 0.750 & 171 & 2 & 0.750 \\
\hline 40 minute & 170 & 0 & 0.782 & 170 & 0 & 0.574 & 170 & 0 & 0.474 & 170 & 0 & 0.711 \\
\hline 50 minute & 171 & 0 & 0.434 & 171 & 0 & 0.297 & 171 & 1 & 0.690 & 171 & 1 & 0.690 \\
\hline \multicolumn{13}{|l|}{1 hour } \\
\hline 1 day & 157 & 0 & 0.266 & 157 & 0 & 0.335 & 157 & 1 & 0.505 & 157 & 1 & 0.505 \\
\hline \multicolumn{13}{|c|}{$x_{t}=$ S\&P 500; $y_{t}=\operatorname{DAX} 30$} \\
\hline 5 minute & 173 & 0 & 0.015 & 173 & \begin{tabular}{|l|} 
\\
\end{tabular} & 0.007 & 173 & 5 & 0.530 & 173 & 4 & 0.842 \\
\hline 10 minute & 172 & 7 & 0.870 & 172 & 7 & 0.545 & 172 & 4 & 0.996 & 172 & 4 & 0.435 \\
\hline 20 minute & 172 & 0 & 0.359 & 172 & 0 & 0.210 & 172 & 0 & 0.645 & 172 & 0 & 0.624 \\
\hline 30 minute & 173 & 1 & 0.006 & 173 & 1 & 0.006 & 173 & 0 & 0.717 & 173 & 0 & 0.459 \\
\hline 40 minute & 172 & 0 & 0.197 & 172 & 0 & 0.152 & 172 & 0 & 0.875 & 172 & 0 & 0.583 \\
\hline 50 minute & 173 & 0 & 0.944 & 173 & 0 & 0.774 & 173 & 1 & 0.949 & 173 & 0 & 0.169 \\
\hline \multicolumn{13}{|l|}{1 hour } \\
\hline 1 day & 122 & 8 & 0.458 & 122 & 8 & 0.458 & 125 & 7 & 0.629 & 125 & 7 & 0.629 \\
\hline \multicolumn{13}{|c|}{$x_{t}=$ FTSE $100 ; y_{t}=$ DAX 30} \\
\hline 5 minute & 174 & 0 & 0.164 & 174 & 0 & 0.153 & 174 & 4 & 0.302 & 174 & 4 & 0.670 \\
\hline 10 minute & 174 & 5 & 0.080 & 174 & 5 & 0.336 & 174 & 2 & 0.432 & 174 & 2 & 0.828 \\
\hline 20 minute & 172 & 7 & 0.100 & 172 & 7 & 0.439 & 172 & 7 & 0.313 & 172 & 7 & 0.920 \\
\hline 30 minute & 173 & 8 & 0.368 & 173 & 8 & 0.685 & 173 & 8 & 0.177 & 173 & 8 & 0.561 \\
\hline 40 minute & 173 & 6 & 0.771 & 173 & 6 & 0.771 & 174 & 0 & 0.269 & 174 & 0 & 0.250 \\
\hline 50 minute & 172 & 3 & 0.487 & 172 & 3 & 0.487 & 173 & 1 & 0.011 & 173 & 1 & 0.011 \\
\hline 1 hour & 173 & 4 & 0.711 & 173 & 4 & 0.711 & 174 & 0 & 0.923 & 174 & 0 & 0.576 \\
\hline 1 day & 167 & 0 & 0.433 & 167 & 0 & 0.301 & 149 & 5 & 0.149 & 149 & 5 & 0.149 \\
\hline \multicolumn{13}{|c|}{$x_{t}=$ FTSE $100 ; y_{t}=$ CAC 40} \\
\hline 5 minute & 175 & 4 & 0.666 & 175 & 4 & 0.997 & 174 & 6 & 0.790 & 174 & 6 & 0.393 \\
\hline 10 minute & 175 & 0 & 0.243 & 175 & 5 & 0.364 & 175 & 4 & 0.259 & 175 & 4 & 0.400 \\
\hline 20 minute & 174 & 7 & 0.193 & 174 & 7 & 0.826 & 174 & 7 & 0.156 & 174 & 7 & 0.886 \\
\hline 30 minute & 174 & 5 & 0.026 & 173 & 8 & 0.109 & 173 & 8 & 0.019 & 173 & 8 & 0.231 \\
\hline 40 minute & 174 & 4 & 0.239 & 174 & 4 & 0.239 & 174 & 4 & 0.884 & 174 & 4 & 0.884 \\
\hline 50 minute & 175 & 0 & 0.679 & 175 & 0 & 0.506 & 172 & 6 & 0.052 & 172 & 6 & 0.052 \\
\hline 1 hour & 175 & 1 & 0.039 & 175 & 0 & 0.049 & 173 & 3 & 0.370 & 173 & 3 & 0.370 \\
\hline 1 day & 152 & 5 & 0.869 & 152 & 5 & 0.869 & 161 & 2 & 0.221 & 161 & 2 & 0.221 \\
\hline
\end{tabular}


Table 6: Continued.

\begin{tabular}{|c|c|c|c|c|c|c|c|c|c|c|c|c|}
\hline \multirow{5}{*}{$\begin{array}{l}\text { Data } \\
\text { frequency }\end{array}$} & \multicolumn{12}{|c|}{ Estimated equation } \\
\hline & \multirow{2}{*}{\multicolumn{6}{|c|}{$\begin{array}{c}\Delta \ln y_{t}=c_{1}+\delta_{1} e_{t-1}+\sum_{i=1}^{K} \alpha_{1 i} \Delta \ln y_{t-i}+\sum_{i=1}^{K} \beta_{1 i} \Delta \ln x_{t-i}+\varepsilon_{t} \\
\text { Residuals } e_{t} \text { from the equation }\end{array}$}} & \multirow{2}{*}{\multicolumn{6}{|c|}{$\begin{array}{c}\Delta \ln x_{t}=c_{1}+\delta_{1} e_{t-1}+\sum_{i=1}^{K} \alpha_{1 i} \Delta \ln x_{t-i}+\sum_{i=1}^{K} \beta_{1 i} \Delta \ln y_{t-i}+\varepsilon_{t} \\
\text { Residuals } e_{t} \text { from the equation }\end{array}$}} \\
\hline & & & & & & & & & & & & \\
\hline & \multicolumn{3}{|c|}{$\ln y_{t}=c+\alpha \ln x_{t}+\varepsilon_{t}$} & \multicolumn{3}{|c|}{$\ln x_{t}=c+\alpha \ln y_{t}+\varepsilon_{t}$} & \multicolumn{3}{|c|}{$\ln y_{t}=c+\alpha \ln x_{t}+\varepsilon_{t}$} & \multicolumn{3}{|c|}{$\ln x_{t}=c+\alpha \ln y_{t}+\varepsilon_{t}$} \\
\hline & Obs. & $K$ & P-value & Obs. & $K$ & P-value & Obs. & $K$ & P-value & Obs. & $K$ & P-value \\
\hline \multicolumn{13}{|c|}{$x_{t}=\operatorname{DAX} 30 ; y_{t}=$ CAC 40} \\
\hline 5 minute & 176 & 8 & 0.124 & 176 & 8 & 0.931 & 177 & 5 & 0.331 & 177 & 5 & 0.932 \\
\hline 10 minute & 177 & 6 & 0.268 & 177 & 6 & 0.491 & 177 & 6 & 0.274 & 177 & 6 & 0.475 \\
\hline 20 minute & 177 & 3 & 0.330 & 177 & 3 & 0.023 & 177 & 3 & 0.506 & 177 & 3 & 0.506 \\
\hline 30 minute & 177 & 3 & 0.684 & 177 & 3 & 0.684 & 175 & 7 & 0.944 & 175 & 7 & 0.944 \\
\hline 40 minute & 177 & 0 & 0.017 & 177 & 0 & 0.012 & 177 & 0 & 0.027 & 177 & 0 & 0.029 \\
\hline 50 minute & 176 & 1 & 0.010 & 176 & 1 & 0.010 & 176 & 1 & 0.153 & 176 & 1 & 0.153 \\
\hline 1 hour & 177 & 1 & 0.005 & 177 & 1 & 0.005 & 177 & 1 & 0.024 & 177 & 1 & 0.024 \\
\hline 1 day & 163 & 6 & 0.540 & 163 & 6 & 0.540 & 172 & 0 & 0.366 & 172 & 0 & 0.413 \\
\hline \multicolumn{13}{|c|}{$x_{t}=$ DAX 30; $y_{t}=$ WIG 20} \\
\hline 5 minute & 174 & 7 & 0.018 & 174 & 7 & 0.696 & \begin{tabular}{|l|}
174 \\
\end{tabular} & 4 & 0.297 & 174 & 6 & 0.223 \\
\hline 10 minute & 174 & 5 & 0.378 & 174 & 5 & 0.059 & 174 & 5 & 0.098 & 174 & 5 & 0.672 \\
\hline 20 minute & 173 & 5 & 0.757 & 173 & 5 & 0.979 & 174 & 0 & 0.275 & 174 & 0 & 0.156 \\
\hline 30 minute & 173 & 4 & 0.552 & 173 & 4 & 0.079 & 173 & 8 & 0.798 & 173 & 8 & 0.827 \\
\hline 40 minute & 174 & 2 & 0.107 & 174 & 0 & 0.037 & 173 & 7 & 0.353 & 173 & 7 & 0.247 \\
\hline 50 minute & 173 & 0 & 0.097 & 173 & 0 & 0.022 & 172 & 3 & 0.787 & 172 & 3 & 0.933 \\
\hline 1 hour & 174 & 0 & 0.766 & 174 & 0 & 0.266 & 173 & 4 & 0.473 & 173 & 4 & 0.869 \\
\hline 1 day & 138 & 6 & 0.046 & 138 & 6 & 0.046 & 166 & 0 & 0.061 & 166 & 0 & 0.043 \\
\hline \multicolumn{13}{|c|}{$x_{t}=\operatorname{DAX} 30 ; y_{t}=\operatorname{PX} 50$} \\
\hline 5 minute & 162 & 3 & 0.472 & 162 & 3 & 0.849 & $164 \mid$ & 4 & 0.635 & 164 & 4 & 0.510 \\
\hline 10 minute & 155 & 6 & 0.999 & 155 & 6 & 0.694 & 163 & 2 & 0.644 & 163 & 2 & 0.805 \\
\hline 20 minute & 157 & 6 & 0.365 & 157 & 6 & 0.356 & 167 & 0 & 0.099 & 163 & 5 & 0.090 \\
\hline 30 minute & 152 & 8 & 0.020 & 152 & 8 & 0.793 & 156 & 8 & 0.309 & 156 & 8 & 0.874 \\
\hline 40 minute & 157 & 6 & 0.020 & 157 & 6 & 0.903 & 170 & 0 & 0.505 & 170 & 0 & 0.474 \\
\hline 50 minute & 104 & 6 & 0.395 & 104 & 6 & 0.145 & 173 & 0 & 0.377 & 173 & 0 & 0.296 \\
\hline 1 hour & 164 & 3 & 0.020 & 164 & 3 & 0.088 & 171 & 0 & 0.057 & 171 & 0 & 0.026 \\
\hline 1 day & 105 & 8 & 0.144 & 105 & 8 & 0.144 & 159 & 0 & 0.046 & 159 & 0 & 0.050 \\
\hline \multicolumn{13}{|c|}{$x_{t}=$ WIG $20 ; y_{t}=$ PX 50} \\
\hline 5 minute & 163 & 2 & 0.294 & 163 & 2 & 0.864 & 154 & 7 & 0.041 & 151 & 8 & 0.967 \\
\hline 10 minute & 154 & 5 & 0.963 & 154 & 5 & 0.901 & 157 & 5 & 0.345 & 157 & 5 & 0.464 \\
\hline 20 minute & 162 & 0 & 0.347 & 162 & 0 & 0.235 & 156 & 8 & 0.953 & 156 & 8 & 0.776 \\
\hline 30 minute & 150 & 8 & 0.878 & 150 & 8 & 0.132 & 162 & 3 & 0.262 & 162 & 3 & 0.822 \\
\hline 40 minute & 155 & 6 & 0.563 & 155 & 6 & 0.875 & 167 & 2 & 0.307 & 167 & 2 & 0.720 \\
\hline 50 minute & 159 & 4 & 0.023 & 159 & 4 & 0.199 & 171 & 2 & 0.355 & 171 & 2 & 0.010 \\
\hline 1 hour & 154 & 4 & 0.791 & 154 & 4 & 0.527 & 169 & 0 & 0.827 & 169 & 0 & 0.827 \\
\hline 1 day & 129 & 4 & 0.045 & 129 & 4 & 0.045 & 153 & 0 & 0.166 & 153 & 0 & 0.155 \\
\hline
\end{tabular}

Notes: Obs. stand for the number of observations and $K$ for the number of lagged differences used in the error correction models. The reported P-values are those for the estimated coefficient $\delta$. 
Table 7: Results of Granger causality tests with different data frequencies.

\begin{tabular}{|c|c|c|c|c|c|c|c|c|}
\hline \multirow{2}{*}{$\begin{array}{l}\text { Data } \\
\text { frequency }\end{array}$} & \multicolumn{4}{|c|}{$\ln x_{t}$ GC $\ln y_{t}$} & \multicolumn{4}{|c|}{$\ln y_{t}$ GC $\ln x_{t}$} \\
\hline & Obs. & $K$ & $R^{2}$ & P-value & Obs. & $K$ & $R^{2}$ & P-value \\
\hline \multicolumn{9}{|c|}{$x_{t}=$ S\&P 500; $y_{t}=$ DJIA } \\
\hline 5 minute & 172 & 5 & 0.087 & 0.062 & 172 & 5 & 0.101 & 0.021 \\
\hline 10 minute & 171 & 8 & 0.107 & 0.517 & 171 & 8 & 0.095 & 0.701 \\
\hline 20 minute & 172 & 1 & 0.010 & 0.849 & 171 & 6 & 0.069 & 0.728 \\
\hline 30 minute & 172 & 1 & 0.008 & 0.834 & 171 & 1 & 0.018 & 0.658 \\
\hline 40 minute & 172 & 1 & 0.028 & 0.763 & 172 & 1 & 0.038 & 0.713 \\
\hline 50 minute & 171 & 1 & 0.045 & 0.999 & 171 & 1 & 0.053 & 0.504 \\
\hline 1 hour & 172 & 1 & 0.043 & 0.917 & 171 & 1 & 0.050 & 0.459 \\
\hline 1 day & 121 & 6 & 0.123 & 0.178 & 113 & 7 & 0.272 & 0.042 \\
\hline \multicolumn{9}{|c|}{$x_{t}=$ S\&P 500; $y_{t}=$ FTSE 100} \\
\hline 5 minute & 171 & 6 & 0.108 & 0.037 & 170 & 7 & 0.129 & 0.239 \\
\hline 10 minute & 170 & 3 & 0.059 & 0.075 & 170 & 4 & 0.048 & 0.170 \\
\hline 20 minute & 170 & 1 & 0.020 & 0.079 & 170 & 1 & 0.008 & 0.255 \\
\hline 30 minute & 171 & 2 & 0.071 & 0.027 & 171 & 2 & 0.038 & 0.116 \\
\hline 40 minute & 170 & 1 & 0.008 & 0.338 & 170 & 1 & 0.011 & 0.627 \\
\hline 50 minute & 171 & 1 & 0.011 & 0.188 & 171 & 1 & 0.025 & 0.689 \\
\hline \multicolumn{9}{|l|}{1 hour } \\
\hline 1 day & 157 & 1 & 0.010 & 0.780 & 157 & 1 & 0.037 & 0.504 \\
\hline \multicolumn{9}{|c|}{$x_{t}=$ S\&P 500; $y_{t}=$ DAX 30} \\
\hline 5 minute & 173 & 1 & 0.046 & 0.006 & 173 & 5 & 0.096 & 0.466 \\
\hline 10 minute & 172 & 7 & 0.098 & 0.604 & 172 & 4 & 0.069 & 0.041 \\
\hline 20 minute & 172 & 1 & 0.018 & 0.212 & 172 & 1 & 0.001 & 0.736 \\
\hline 30 minute & 173 & 1 & 0.068 & 0.006 & 173 & 1 & 0.014 & 0.816 \\
\hline 40 minute & 172 & 1 & 0.012 & 0.179 & 172 & 1 & 0.011 & 0.648 \\
\hline 50 minute & 173 & & 0.004 & 0.892 & 173 & 1 & 0.025 & 0.949 \\
\hline \multicolumn{9}{|l|}{1 hour } \\
\hline 1 day & 122 & 8 & 0.135 & 0.435 & 125 & 7 & 0.207 & 0.030 \\
\hline \multicolumn{9}{|c|}{$x_{t}=$ FTSE $100 ; y_{t}=$ DAX 30} \\
\hline 5 minute & 174 & 1 & 0.012 & 0.173 & 174 & 4 & 0.094 & 0.102 \\
\hline 10 minute & 174 & 5 & 0.091 & 0.062 & 174 & 2 & 0.073 & 0.208 \\
\hline 20 minute & 172 & 7 & 0.109 & 0.086 & 172 & 7 & 0.126 & 0.146 \\
\hline 30 minute & 173 & 8 & 0.081 & 0.408 & 173 & 8 & 0.084 & 0.970 \\
\hline 40 minute & 173 & 6 & 0.090 & 0.127 & 174 & 1 & 0.008 & 0.432 \\
\hline 50 minute & 172 & 3 & 0.044 & 0.361 & 173 & 1 & 0.039 & 0.011 \\
\hline 1 hour & 173 & 4 & 0.107 & 0.090 & 174 & 1 & 0.027 & 0.203 \\
\hline 1 day & 167 & 1 & 0.015 & 0.622 & 149 & 5 & 0.060 & 0.312 \\
\hline \multicolumn{9}{|c|}{$x_{t}=$ FTSE $100 ; y_{t}=$ CAC 40} \\
\hline 5 minute & 175 & 4 & 0.065 & 0.455 & 174 & 6 & 0.099 & 0.218 \\
\hline 10 minute & 175 & 5 & 0.065 & 0.568 & 175 & 4 & 0.094 & 0.163 \\
\hline 20 minute & 174 & 7 & 0.124 & 0.133 & 174 & 7 & 0.122 & 0.190 \\
\hline 30 minute & 173 & 7 & 0.056 & 0.471 & 173 & 8 & 0.111 & 0.604 \\
\hline 40 minute & 174 & 4 & 0.040 & 0.231 & 174 & 4 & 0.053 & 0.147 \\
\hline 50 minute & 175 & 1 & 0.010 & 0.524 & 172 & 6 & 0.089 & 0.238 \\
\hline 1 hour & 175 & 1 & 0.037 & 0.039 & 173 & 3 & 0.048 & 0.397 \\
\hline 1 day & 152 & 5 & 0.049 & 0.373 & 161 & 2 & 0.050 & 0.153 \\
\hline
\end{tabular}


Table 7: Continued.

\begin{tabular}{|c|c|c|c|c|c|c|c|c|}
\hline \multirow{2}{*}{$\begin{array}{l}\text { Data } \\
\text { frequency }\end{array}$} & \multicolumn{4}{|c|}{$\ln x_{t}$ GC $\ln y_{t}$} & \multicolumn{4}{|c|}{$\ln y_{t}$ GC $\ln x_{t}$} \\
\hline & Obs. & $K$ & $\mathbf{R}^{2}$ & P-value & Obs. & $K$ & $\mathbf{R}^{2}$ & P-value \\
\hline \multicolumn{9}{|c|}{$x_{t}=\operatorname{DAX} 30 ; y_{t}=$ CAC 40} \\
\hline 5 minute & 176 & 8 & 0.133 & 0.105 & 177 & 5 & 0.083 & 0.411 \\
\hline 10 minute & 177 & 6 & 0.119 & 0.068 & 177 & 6 & 0.124 & 0.011 \\
\hline 20 minute & 176 & 4 & 0.074 & 0.064 & 177 & 3 & 0.059 & 0.093 \\
\hline 30 minute & 177 & 3 & 0.050 & 0.062 & 175 & 7 & 0.070 & 0.179 \\
\hline 40 minute & 177 & 1 & 0.041 & 0.009 & 177 & 1 & 0.028 & 0.045 \\
\hline 50 minute & 176 & 1 & 0.050 & 0.009 & 176 & 1 & 0.022 & 0.152 \\
\hline 1 hour & 177 & 1 & 0.060 & 0.005 & 177 & 1 & 0.078 & 0.024 \\
\hline 1 day & 163 & 6 & 0.062 & 0.217 & 172 & 1 & 0.010 & 0.680 \\
\hline \multicolumn{9}{|c|}{$x_{t}=$ DAX $30 ; y_{t}=$ WIG 20} \\
\hline 5 minute & 174 & 7 & 0.217 & 0.037 & 174 & 4 & 0.087 & 0.209 \\
\hline 10 minute & 174 & 5 & 0.071 & 0.480 & 174 & 5 & 0.070 & 0.272 \\
\hline 20 minute & 173 & 5 & 0.092 & 0.735 & 174 & 1 & 0.022 & 0.725 \\
\hline 30 minute & 173 & 4 & 0.092 & 0.432 & 173 & 8 & 0.048 & 0.961 \\
\hline $40 \mathrm{~m}$ & 174 & 2 & 0.061 & 0.041 & 173 & 7 & 0.089 & 0.211 \\
\hline 50 minute & 173 & 1 & 0.049 & 0.005 & 172 & 3 & 0.050 & 0.211 \\
\hline 1 hour & 174 & 1 & 0.050 & 0.012 & 173 & 4 & 0.075 & 0.955 \\
\hline 1 day & 138 & 6 & 0.106 & 0.124 & 166 & 1 & 0.025 & 0.140 \\
\hline \multicolumn{9}{|c|}{$x_{t}=\mathrm{DAX} 30 ; y_{t}=\mathrm{PX} 50$} \\
\hline 5 minute & 162 & 3 & $\begin{array}{l}0.128 \\
\end{array}$ & 0.006 & 164 & 4 & 0.072 & 0.614 \\
\hline 10 minute & 155 & 6 & 0.195 & 0.006 & 163 & 2 & 0.046 & 0.066 \\
\hline 20 minute & 157 & 6 & 0.149 & 0.011 & 167 & 1 & 0.022 & 0.824 \\
\hline 30 minute & 152 & 8 & 0.150 & 0.247 & 156 & 8 & 0.071 & 0.670 \\
\hline 40 minute & 157 & 6 & 0.100 & 0.669 & 170 & 1 & 0.004 & 0.882 \\
\hline 50 minute & 104 & 6 & 0.168 & 0.365 & 173 & 1 & 0.015 & 0.435 \\
\hline 1 hour & 164 & 3 & 0.078 & 0.311 & 171 & 1 & 0.053 & 0.435 \\
\hline 1 day & 105 & 8 & 0.127 & 0.533 & 159 & 1 & 0.025 & 0.113 \\
\hline \multicolumn{9}{|c|}{$x_{t}=$ WIG $20 ; y_{t}=$ PX 50} \\
\hline 5 minute & 163 & 2 & 0.070 & 0.465 & 151 & 8 & 0.175 & 0.592 \\
\hline 10 minute & 154 & 5 & 0.141 & 0.128 & 157 & 5 & 0.086 & 0.564 \\
\hline 20 minute & 162 & 1 & 0.048 & 0.054 & 156 & 8 & 0.182 & 0.042 \\
\hline 30 minute & 150 & 8 & 0.173 & 0.078 & 162 & 3 & 0.078 & 0.156 \\
\hline 40 minute & 155 & 6 & 0.125 & 0.225 & 167 & 2 & 0.044 & 0.221 \\
\hline 50 minute & 159 & 4 & 0.093 & 0.516 & 171 & 2 & 0.043 & 0.041 \\
\hline 1 hour & 154 & 4 & 0.127 & 0.040 & 169 & 1 & 0.074 & 0.002 \\
\hline 1 day & 129 & 4 & 0.094 & 0.067 & 153 & 1 & 0.013 & 0.367 \\
\hline
\end{tabular}


CERGE-EI

P.O.BOX 882

Politických vězňů 7

11121 Praha 1

Czech Republic http://www.cerge-ei.cz 